Annals of Warsaw University of Life Sciences - SGGW

Land Reclamation No 48 (4), 2016: 353-363

(Ann. Warsaw Univ. Life Sci. - SGGW, Land Reclam. 48 (4), 2016)

\title{
Geomorphological analysis in soil profile assessment of the margin of Warsaw morainic plateau in Ursynów
}

\author{
KAZIMIERZ GARBULEWSKI, TOMASZ FALKOWSKI, \\ SIMON RABARIJOELY, PIOTR OSTROWSKI \\ Department of Geotechnical Engineering, Warsaw University of Life Sciences - SGGW
}

\begin{abstract}
Geomorfological analysis in soil profile assessment of the margin of Warsaw morainic plateau in Ursynów. This paper addresses the application of geomorphological analysis to recognize the geotechnical conditions at the margin of a moraine plateau in Warsaw. Aerial photographs, borehole data logging, CPT and DMT tests results were taken into account to compare the conditions at two sites, i.e. the well recognized part of the moraine plateau (SGGW Stadium site) and the second part located at a distance of $5 \mathrm{~km}$ (Warsaw slope - church). Spatial variability of the strength and deformation properties in the study areas were determined using CPT and DMT tests results. The general conclusion is that the specific geomorphological units allow for prediction to some extent the sequence of geotechnical layers and the general distribution of soil parameters. The example from the margin of the moraine plateau in Warsaw shows that such procedure is a promising statistical tool related to geotechnical problems.
\end{abstract}

Key words: geomorphological form, ground characterisation, geotechnical mapping, morainic plateau

\section{INTRODUCTION}

The aim of this paper is to show how geomorphological, landform analysis can be applied to approximate the geotechnical conditions of the design structure (Garbulewski et al. 2009). Properties of the subsoil are the result of the geological history of the area, comprising the processes of deposition, diagenesis, and the nature as well as intensity of denudation processes. Their effect, apart from specific lithological profile and pattern of exposure, is also the land morphology. In the Polish Lowlands, the most clear relationship between the morphological features and the lithological/sedimentological diversity is represented by the fluvial environment. Apart from the importance of rock boundaries that reveal different resistance to erosion, the effects of fluvial processes result in the spatial arrangement of the outcrops which very often constitute a precise record of changes in the hydrological regime of rivers. Their record in the valley bottom are mainly alluvial terrace landforms, as well as their surface relief (Falkowski 1982).

In the area of post-glacial uplands, lithological and morphological differentiation stems from the dynamics and course of Scandinavian ice sheet transgression and deglaciation processes (Boulton 1979), as well as processes 
dominating in the periglacial zone (Jahn 1975, Szwarczewski 2007). Certain types of surfaces in the Polish Lowlands may be related even to certain types of lithological profiles.

The variable evolution of glacial morphogenesis and lithogenesis, which is related, for example to different bedrock susceptibility, results in the diversity of the lithological profile in all regional zones of the post-glacial landscape. Despite the fact that the present
The aim of this study is to determine the usefulness of morphogenetic analysis in predicting the geotechnical conditions in a selected area of the Polish Lowlands. The selected study area (Fig. 1) covers areas the margin of the denudated moraine plateau in the border zone of the Vistula river valley. Besides the two types of landscape, the study area includes the margin of the plateau, within which slope processes are being observed.

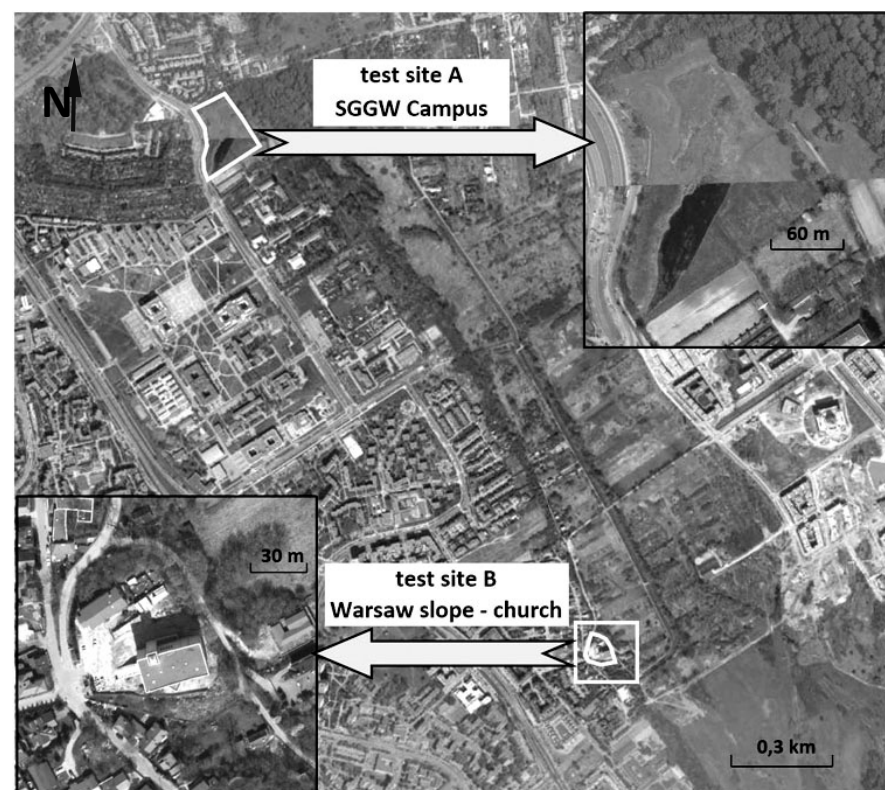

FIGURE 1. Aerial photograph of the margin of the moraine plateau in Warsaw with location of the study sites

morphology was also shaped by processes of denudation, traces of primary, glacial origin are still recognizable in the surface lithology, spatial pattern of the outcrops, as well as the types and distribution of certain landforms.

\section{IDENTIFICATION OF LANDFORMS}

Remote sensing methods are now, beside field studies, an important way to identify landforms. Very high resolution commercial satellite systems (VHRS), airborne laser scanning (ALS) and re- 
cently rapidly developing terrestrial laser scanning (TLS) allow efficient identification of landforms in such diverse environments as the river valleys of Central Europe (Wierzbicki et al. 2013) or polar areas (Kociuba et al. 2013). In many cases the use of remote sensing allows for limit field studies and thus reduce cost and time to solve engineering problems set at the junction of geotechnics, geology and geomorphology. The prevention of dangerous phenomena such as the loss of slope stability (landslides) or hydraulic engineering infrastructure (e.g. levees) failure during floods can be solved using remote sensing methods.

In the case of identifying geomorphological units of different size with the usage of satellite images, spatial resolution is the key parameter. A breakthrough in this area occurred in 1999, when IKONOS 2 began to operate. The IKONOS 2 is the first civil high-resolution commercial satellite carrying satellite images with a spatial resolution of less than $1 \mathrm{~m}$ (Cook et al. 2001). The orbiting satellites placed in 2001-2013 give images with spatial resolution below or equal to $0.5 \mathrm{~m}$ (e.g. WorldView-1, GeoEye-1, WorldView-2, Pléiades 1A/1B). Precise identification of landforms for most VHRS satellite systems also allows high spectral resolution. Images are recorded simultaneously on several channels. This allows the creation and analysis of color composition both in natural and unnatural colors. Of particular importance are compositions in unnatural colors using near-infrared.
On August 13, 2014 the first civil commercial multispectral satellite system of spatial resolution $0.31 \mathrm{~m}$ (WorldView-3) was launched on orbit. It is capable of real-time transmission of data

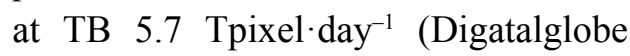
2014). The role of satellite imaginary analysis to identify morphological features and certain landforms seems to have increased.

\section{MARGIN OF THE MORAINE PLATEAU IN WARSAW}

\section{Geological and geotechnical conditions}

The discussed research sites are located in the marginal zone of the south part of Warsaw moraine upland in Ursynów (Fig. 1). In the basement of the Quaternary there are Tertiary deposits, represented by lacustrine Pliocene "motley clays" (Sarnacka 1992). Above the Pliocene deposits there are the preglacial (Eo-Pleistocene) alluvial deposits comprising quartz gravels, sands and silts with lydites. In the Ursynów upland (SGGW Stadium and Warsaw slope - church), above the preglacial deposits, or directly on the lacustrine Pliocene clays, lies a series assigned to the South-Polish Glaciation - boulder clays, glaciofluvial sediments and ice-dammed deposits, which form non-continuous layers. Over these sediments occurs a 15 to $25-\mathrm{m}$ thick formation of river-originated sediments from the Mazovian Interglacial (Sarnacka 1992). It consists mostly of sands and gravels. The top of 
these sediments is located at the depth of from 10 to $20 \mathrm{~m}$ below the ground level. In the Ursynów region these sediments form a continuous, distinct layer, consisting mostly of fine sands.

Above the fluvioglacial sediments lies a layer of melt-out sediments from the Odranian Glaciation, represented by grey boulder clay. The thickness of the clay layer $\left({ }^{\mathrm{g}} \mathrm{Q}_{\mathrm{p}} \mathrm{O}\right.$, Fig. 2$)$ is from several to tens of meters. In some places, the Odranian boulder clay is covered by fluvioglacial sands and gravel or/and icedammed silts. Above them or directly on the boulder clay (as in the case of the SGGW Stadium site), occurs the melt-out till from the Wartanian Glaciation (the last glaciation in this area) $\left({ }^{\mathrm{g}} \mathrm{Q}_{\mathrm{p}} \mathrm{W}\right.$, Fig. 2). It has the form of from brown sandy boulder clay (Sarnacka 1992) with a thickness of from about 2 to $5 \mathrm{~m}$.
Considering the physical and mechanical ground properties in the Stadium test site, there are five geological layers. The first layer consists of fluvioglacial sediments of the Wartanian Glaciation $\left({ }^{\mathrm{fg}} \mathrm{Q}_{\mathrm{p}} \mathrm{W}\right)$ : medium and fine sands, with $I_{D}=(0.35-0.55)$ and clayey sands with sandy clays and silts, for which $I_{L}=(0.15-0.20)$. The second layer comprises the ice-dammed deposits of the Wartanian Glaciation $\left({ }^{b} Q_{p} W\right)$ : medium and fine sands with the density index $I_{D}=(0.3-0.5)$ and sandy clays and clayey sands, for which $I_{L}=(0.0-0.2)$ or $I_{L}=(0.25-0.54)$. The third layer encompasses brown glacial boulder clay of the Wartanian Glaciation $\left({ }^{\mathrm{g}} \mathrm{Q}_{\mathrm{p}} \mathrm{W}\right)$ and sandy clays, for which $I_{L}=(0.0-0.11)$. The fourth layer includes the grey glacial boulder clay of the Odranian Glaciation $\left({ }^{\mathrm{g}} \mathrm{Q}_{\mathrm{p}} \mathrm{O}\right)$ and sandy clays with boulders,

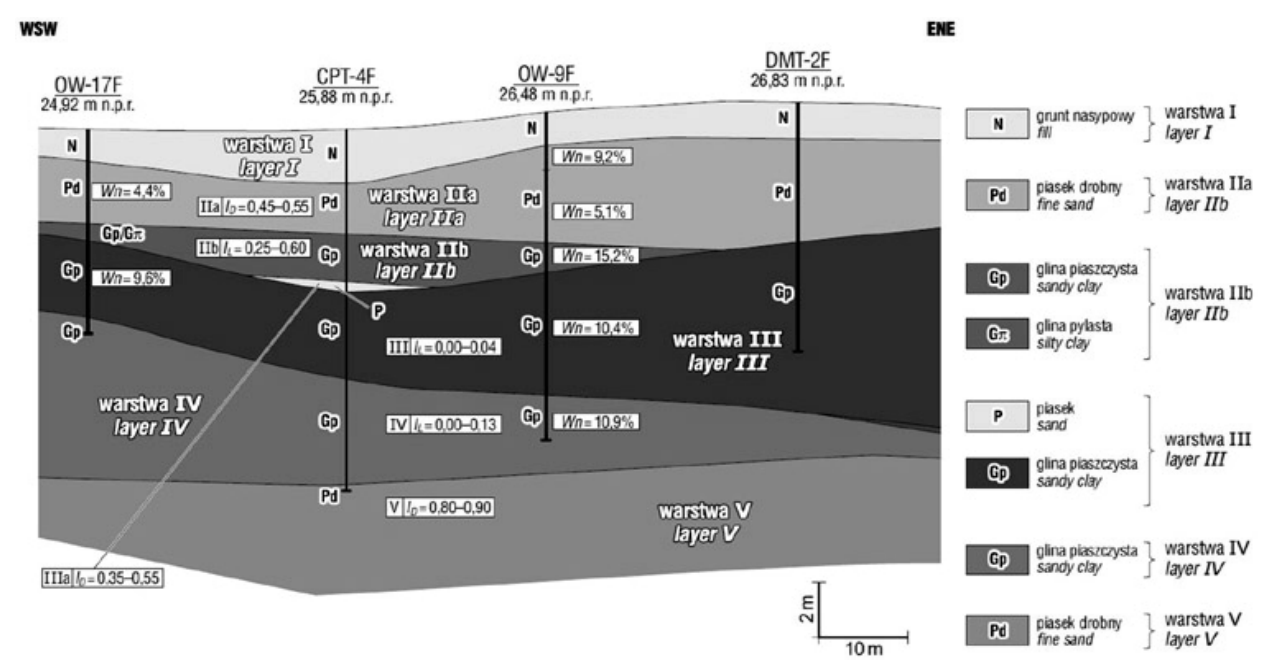

FIGURE 2. Typical geotechnical cross-section of the SGGW Stadium site: $w_{n}$ - moisture content, $I_{D}$ - relative density, $I_{L}-$ liquidity index, $\mathrm{m}$ n.p.r. (meters above the river level) 
for which $I_{L}=(0.0-0.12)$. The last layer undelies river deposits of the Mazovian Interglacial ( $\left.{ }^{f} Q_{p} M\right)$ : fine and medium-grained sands in the roof of the very dense layer with $I_{D}=(0.8-0.9)$.

In order to recognize the soil types distinguished in the subsoils of both analysed sites the Marchetti (1980) chart based on the DMT tests results was applied (Fig. 3). Moreover the chart pro- posed by Robertson et al. (1986) based on CPTu test results (Fig. 3). was used for verification of soil types obtained from the Marchetti chart.

\section{Geomorphological units conditions}

Interpretation of the geomorphology of the upland marginal zone (Warsaw slopes) was based on LIDAR data. In

a

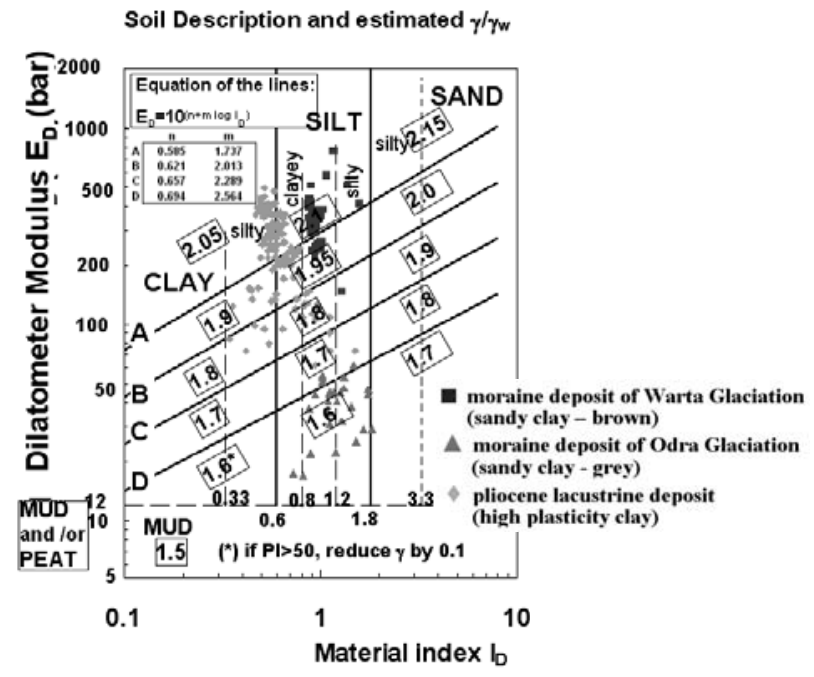

b

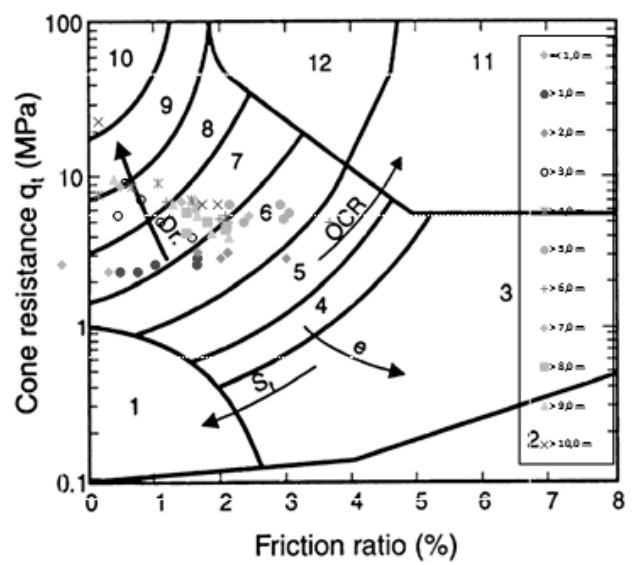

FIGURE 3. Marchetti (a) and Robertson et al. (b) charts respectively based on DMT and CPT test results 
the GIS database (ArcGIS 10.2), elevation data from Airborne Laser Scanning (ALS) were used. The data were analyzed in the ARC/INFO ASCII GRID format - the text files were stored in the form of a matrix containing the values of the number of points in a regular grid with a mesh of $0.5 \mathrm{~m}$. Data in this format provide a very high $(0.5 \mathrm{~m})$ spatial resolution comparable to the resolution of images in VHRS. In order to conduct a detailed analysis of the investigated fragment of the plateau, a characteristic palette of colors was created (Fig. 4).

The location of the landforms limits has been determined based on the analyses of remote sensing satellite images and airborne laser scanning. As a result,
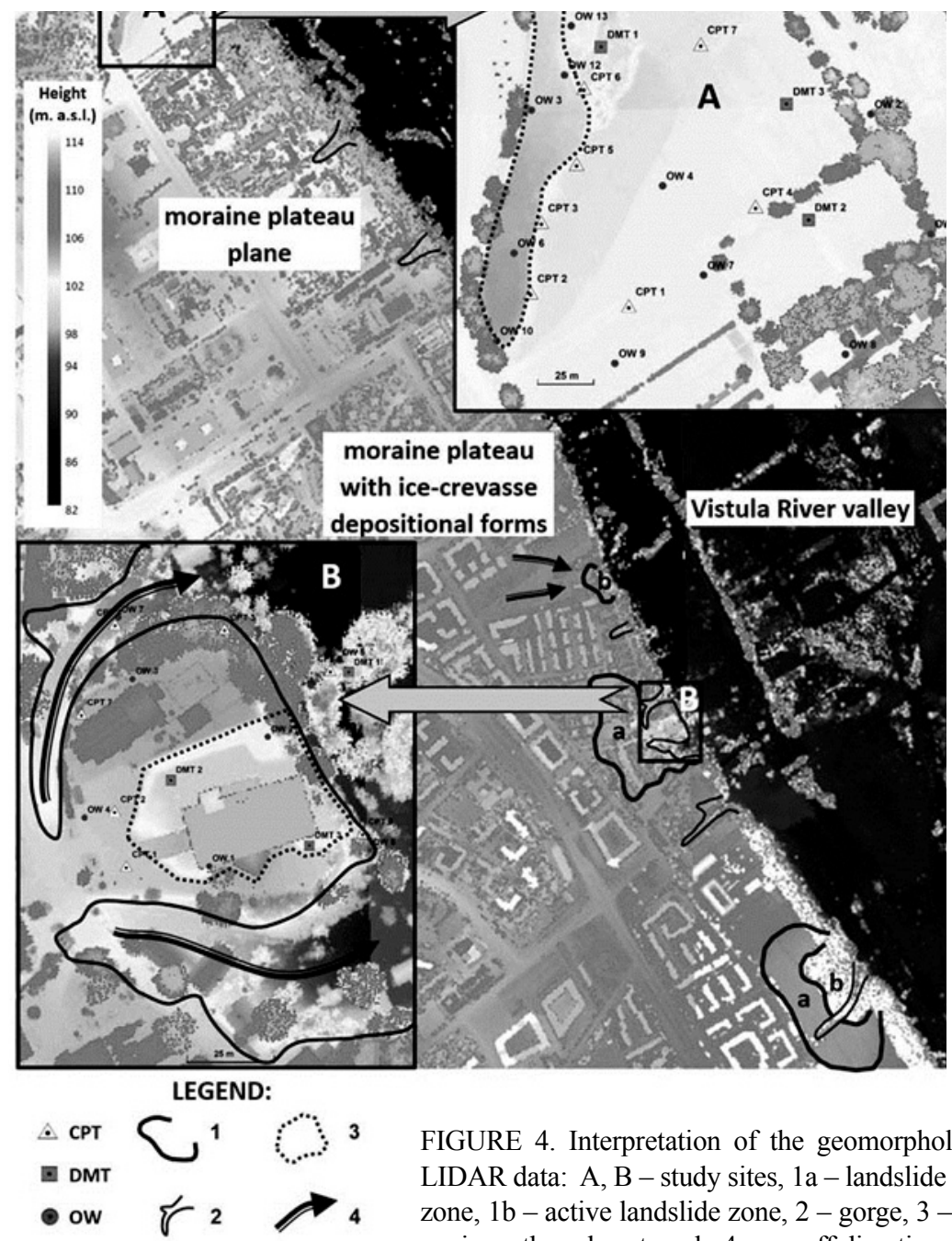

FIGURE 4. Interpretation of the geomorphology using LIDAR data: A, B - study sites, la - landslide catchment zone, $1 \mathrm{~b}$ - active landslide zone, 2 - gorge, 3 - anthropogenic earthwork or trench, 4 - runoff direction 
the following landforms were recognized: (i) narrow eroded gorges (ii) zone of active slope processes (mainly landslides), (iii) monadnocks zone associated with the occurrence of glaciotectonic disturbances and crevasse deposition forms (church), (iv) area of the moraine plateau surface (stadium). carried out in accordance with the useful recommendations of Marchetti (1980), Marchetti and Crapps (1981), Młynarek (2009), Wysokiński (2011), Wrzesiński and Lechowicz (2013), Wierzbicki and Młynarek (2015), Młynarek et al. (2016). As shown in Figure 5, the profiles of $I_{D}$, $K_{D}$ and $E_{D}$ indexes (average values) from the DMT tests obtained for the subsoil
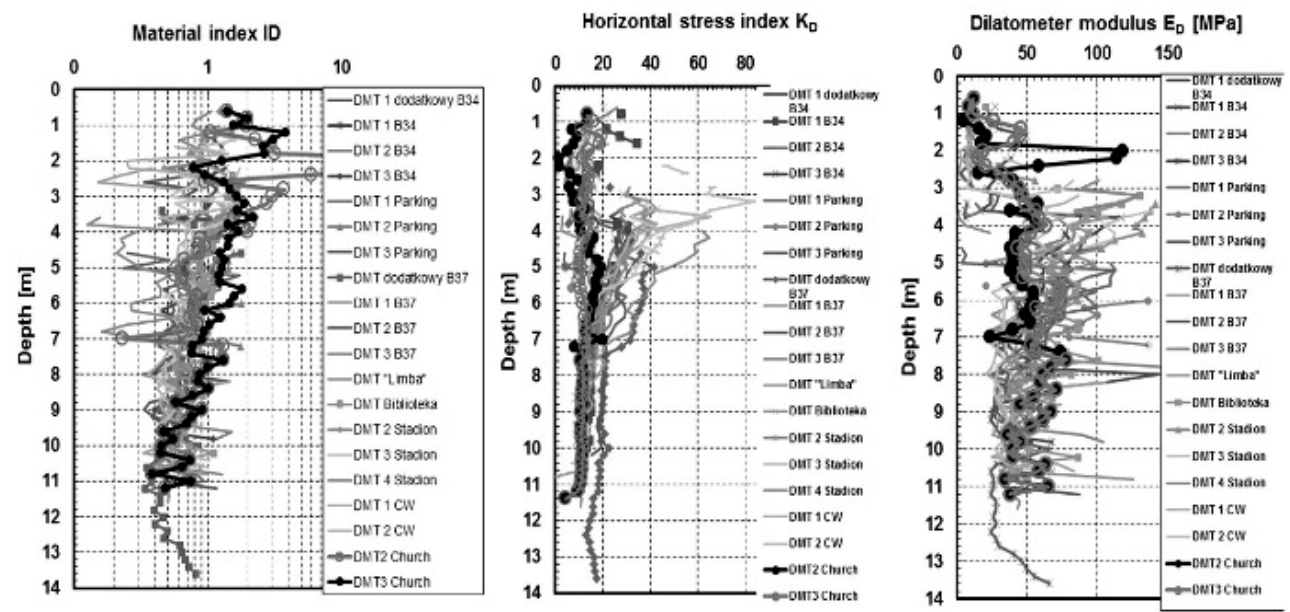

FIGURE 5. Profiles of $I_{D}, K_{D}$ and $E_{D}$ indexes from the DMT tests carried out for the subsoil of the WULS-SGGW Campus and Warsaw slope (church)

\section{Predicted geotechnical conditions in particular landforms}

Geotechnical conditions in the subsoil of the test sites were recognized using aerial photographs, borehole data logging, CPT and DMT tests. The sequence of geotechnical layers in site B (Warsaw slope - church) is similar to that detected in the subsoil profile of site A (WULS-SGGW Campus - see Fig. 4). The interpretation of DMT tests was of the WULS-SGGW Campus (site A) and Warsaw slope (site B) are similar. The distribution of average values of the constrained modulus $(M)$ and undrained shear strength $\left(\tau_{f u}\right)$ are also comparable (Fig. 6).

The distribution of constrained modulus $(M)$ in the subsoils of both analysed sites was obtained using the empirical correlations proposed by Marchetti (1980) for $0.6<I_{D}<3.0$ as follows: 

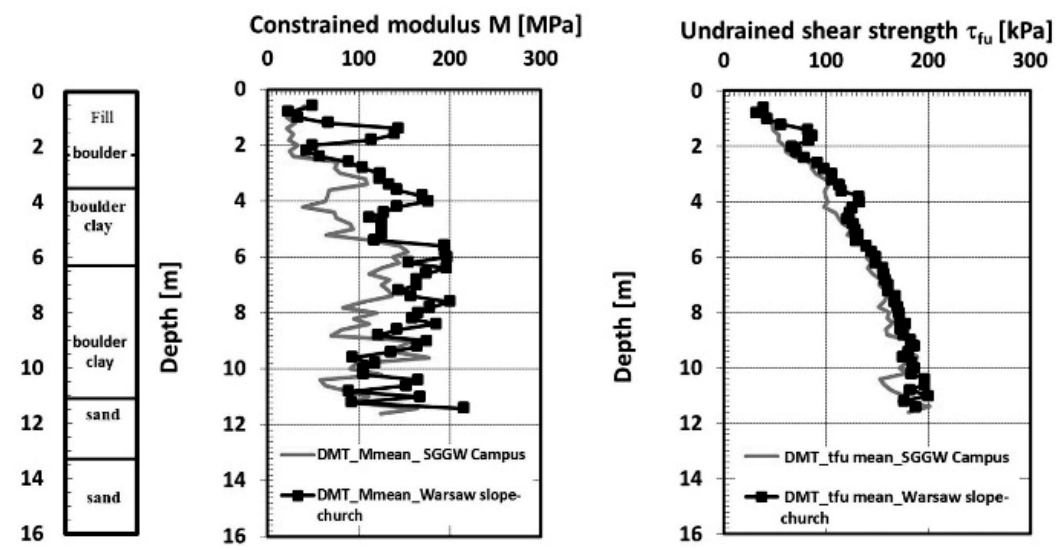

FIGURE 6. Constrained modulus $(M)$ and undrained shear strength from the DMT test for the subsoil of the WULS-SGGW Campus and Warsaw slope (church)

where:

$$
M=R_{M} \cdot E_{D}
$$

$R_{M}$ - factor related to $K_{D}$ and $I_{D}$;

$K_{D}-$ horizontal stress index;

$I_{D}$ - material index;

$E_{D}$ - dilatometer modulus.

The factor $R_{M}$ was determinated using formula proposed by Lechowicz et al. (2011):

$$
R_{M}=0.14+1.6 \cdot \log K_{D}
$$

The distribution of undraned shear strength $\left(\tau_{f u}\right)$ in the analysed subsoils was obtained using the empirical correlations proposed by Marchetti (1980) as follows:

$$
\tau_{f u}=\sigma_{v}^{\prime} \cdot 0.22\left(0.5 \cdot K_{D}\right)^{1.25}
$$

The distribution of constrained modulus $(M)$ and undraned shear strength $\left(\tau_{f u}\right)$ depend strongly on the distribution of overconsolidation ratio $(O C R)$. Therefore the distibution of $O C R$ in the ana- lysed sites was presented in Figure 7. To determine the $O C R$ the empirical Marchetti (1980) correlation was applied for $1.2<I_{D}<2$ :

$$
\begin{aligned}
& \text { OCR }=\left(m \cdot K_{D}\right)^{n} \\
& m=0.5+0.17 \cdot p \\
& n=1.56+0.35 \cdot p \\
& p=\left(I_{D}-1.2\right) / 0.8
\end{aligned}
$$

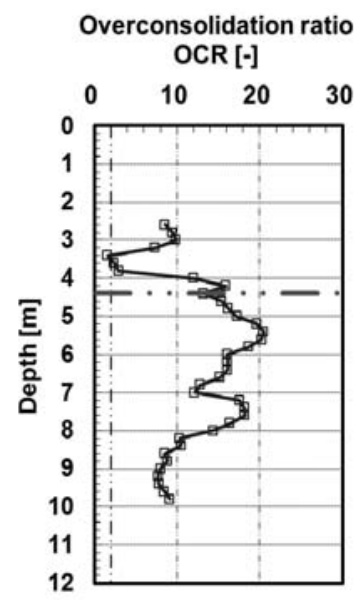

FIGURE 7. Profile of $O C R$ in the WULS-SGGW Campus 
FINAL REMARKS

\section{AND CONCLUSIONS}

Geomorphological interpretation of an area such as the margin of the moraine plateau in Warsaw is very difficult due to very small differences in the altitude within the moraine and its significant transformation caused by urbanization. Despite that, the use of LIDAR data with high spatial resolution allows for the fairly precise identification of geomorphological units (landforms) and their characteristics in the study area. In this case, data from airborne laser scanning (ALS) interpreted in the form of raster data (ASCII GRID) seems to be more useful than classical geomorphological mapping, aerial photographs and satellite images.

It is assumed that in similar landforms can be distinguished similar geotechnical conditions (type and sequence of geotechnical layers, general distribution of deformation and strength parameters). Analysis of the margin of the Warsaw plateau has confirmed to some extent the sensibility and validity of certain assumptions. In both parts of the analyzed slope there is a similar layout and types of subsoil. In addition, the distribution of parameters obtained during DMT tests is comparable. The reason for this similarity is that lithological profiles of both studied areas show only little advanced slope processes. Area of the church location, despite the fact that it is located in the zone of the escarpment is the monadnock. It is cut off from the plateau with two erosional gorges.

In the Warsaw escarpment belt in Ursynów there are areas, where lithological profiles reveal distinct differences of geotechnical properties (compare with Bąkowska et al. 2016). Therefore, a general conclusion can be drawn that specific geomorphological units recognition allow for prediction the range of geotechnical conditions. The example from the margin of the moraine plateau in Warsaw shows that such procedure is a powerful and promising statistical tool related to geotechnical problems.

Conclusions drawn in this paper were developed only on the basis of a comparison of only two units of a certain landform - the margin of a moraine plateau. It should be pointed out that the geomorphological units selected to verify the assumptions is very complex and difficult to analyze. In the case of other landforms, which are more uniform, the proposed idea will be more appropriate. After wider and more comprehensive analysis of various geomorphological units more definite conclusions can be formulated.

\section{REFERENCES}

BAKOWSKA A., DOBAK P., GAWRIUCZENKOW I., KIEŁBASIŃSKI K., SZCZEPAŃSKI T., TRZCIŃSKI J., WÓJCIK E., ZAWRZYKRAJ P. 2016: Stress-strain behaviour analysis of Middle Polish glacial tills from Warsaw (Poland) based on the interpretation of advanced field and laboratory tests. Acta Geol. Pol. 66 (3), 561-585. 
BOULTON G.S. 1979: Processes of glacial erosion on different substrata. J. Glaciol. 23, 15-38.

FALKOWSKI E. 1982: Some regularities of the valley floor evolution of the Middle Vistula river valley. In: L. Starkel (Ed.). Evolution of the Vistula river valley during the last 15000 years. Geogr. Stud. IGiPZ PAN 1, 9-20.

GARBULEWSKI K., JABŁONOWSKI S., RABARIJOELY S. 2009: Advantage of Bayesian approach to geotechnical designing. Ann. Warsaw Univ. of Life Sci. - SGGW, Land Reclam. 41 (2), 83-93.

JAHN A. 1975: Problems of the periglacial zone. PWN, Warszawa.

KOCIUBA W., KUBISZ W., ZAGÓRSKI P. 2013: Use of terrestrial laser scanning (TLS) for monitoring and modelling of geomorphic processes and phenomena at a small and medium spatial scale in Polar environment (Scott River - Spitsbergen). Geomorphology 212, 84-96.

LECHOWICZ Z., RABARIJOELY S., GALAS P., KIZIEWICZ D. 2011: Settlement evaluation of spread foundations on heavily preconsolidated cohesive soils. Ann. Warsaw Uni. Life Sci. - SGGW, Land Reclam. 43 (2), 111-118.

MARCHETTI S. 1980: In Situ Tests by Flat Dilatometer. J. Geotech. Eng. Div. ASCE 106, GT3, 299-321.

MARCHETTI S., CRAPPS D.K. 1981: Flat dilatometer manual. Internal report of GPE.

MŁYNAREK Z. 2009: Subsoil contribution to construction failures. Proceedings of XXIV Conference "Awarie budowlane", Międzyzdroje.

MŁYNAREK Z., WIERZBICKI J., LUNNE T. 2016: On the influence of overconsolidation effect on the compressibility assessment of subsoil by means of CPTU and DMT. Ann. Warsaw Univ. of Life Sci. - SGGW, Land Reclam. 48 (3), 189-200.

ROBERTSON P.K., CAMPANELLA, R.G., GILLESPIE D., GREIG J. 1986: Use of Piezometer Cone data. In-Situ' 86 Use of In-situ testing in Geotechnical Engineering, GSP 6, ASCE, Reston, VA, Specialty Publication.

SARNACKA Z. 1992: Stratigraphy of quaternary sediments of Warsaw and its vicinity. Pr. Państw. Inst. Geol. 138, 1-36.
SZWARCZEWSKI P. 2007: Multistage erosion processes in the Ursynów Scarp area (Warsaw). Pr. Inst. Geogr. Akademii Świętokrzyskiej w Kielcach 16, 157-171.

WIERZBICKI J., MŁYNAREK Z. 2015: Representative value of geotechnical parameters from in situ test and its use to construct of geotechnical models. Inż. Mor. i Geotech. 36, $3,166-176$.

WIERZBICKI G. OSTROWSKI P. MAZGAJSKI M., BUJAKOWSKI F. 2013: Using VHR multispectral remote sensing and LIDAR data to determine the geomorphological effects of overbank flow on a floodplain (the Vistula River, Poland). Geomorphology $183,73-81$.

WRZESIŃSKI G., LECHOWICZ Z. 2013: Influence of the rotation of principal stress directions on undrained shear strength. Ann. Warsaw Univ. Life Sci. - SGGW, Land Reclam. 45 (2), 183-192.

WYSOKIŃSKI L., KOTLICKI W., GODLEWSKI T. 2011: Geotechnical design according to Eurocode 7. Instytut Techniki Budowlanej, Warszawa.

Streszczenie: Analiza geomorfologiczna w ocenie profilu gruntowego wysoczyzny morenowej na Ursynowie $w$ Warszawie. Artykuł przedstawia przykład wykorzystania analizy form rzeźby w strefie krawędziowej wysoczyzny morenowej w Warszawie w celu rozpoznania warunków geotechnicznych na tym obszarze. Wyniki analizy geomorfologicznej wykonanej głównie na podstawie danych $\mathrm{z}$ lotniczego skaningu laserowego (ALS) zostały porównane $\mathrm{z}$ wynikami wierceń i badań CPT oraz DMT. Analizowano dwa oddalone od siebie o około $5 \mathrm{~km}$ fragmenty wysoczyzny morenowej zlokalizowane w bezpośrednim sąsiedztwie skarpy warszawskiej. Przestrzenną zmienność parametrów wytrzymałościowych i odkształceniowych na badanych obszarach wyznaczono, korzystając z wyników sondowań CPT i badań dylatometrycznych (DMT). Uzyskane wyniki pozwoliły na sformułowanie wniosku, że analizy geomorfologiczne mogą być przydatne w rozpoznaniu zróżnicowania przestrzennego parametrów geotechnicznych podłoża gruntowego. 
MS received June 2016

Authors' address:

Kazimierz Garbulewski

Katedra Geoinżynierii

Wydział Budownictwa i Inżynierii Środowiska

SGGW

ul. Nowoursynowska 159, 02-776 Warszawa

Poland

e-mail: kazimierz_garbulewski@sggw.pl 